\title{
QUALITY OF LIFE IN BIPOLAR AND UNIPOLAR DEPRESSIVE PATIENTS: CLINICAL AND SOCIO- DEMOGRAPHICAL CORRELATES
}

\author{
Aftab Ahmed Khan'1, Swapnil Agrawal2, Rahila Qureshi³, Vikash Sharma4 \\ ${ }^{1}$ Assistant Professor, Department of Psychiatry, NSCB Medical College, Jabalpur, Madhya Pradesh. \\ ${ }^{2}$ Senior Resident, Department of Psychiatry, NSCB Medical College, Jabalpur, Madhya Pradesh. \\ ${ }_{3}^{3}$ Medical Officer, Department of PH \& FW, Jabalpur, Madhya Pradesh. \\ 4Junior Resident, Department of Psychiatry, NSCB Medical College, Jabalpur, Madhya Pradesh.
}

\section{ABSTRACT}

The concept of Quality of Life is becoming an increasingly important measure of the impact of psychiatric disorders and is now recognized as useful in the healthcare evaluation of patients with psychiatric disorders. This cross-sectional study examined the relationships between clinical and sociodemographic variables and self-reported quality of life (QOL) in 30 bipolar depressive patients and 30 unipolar depressive patients Participants were administered the World Health Organization Quality of Life MeasureAbbreviated Version (WHOQOL-BREF) to assess QOL.

\section{AIMS AND OBJECTIVE}

The aims of this study were (i) to compare Quality of Life (QOL) of patients with bipolar depression to those with unipolar depression and (ii) to assess the association of different domains of QOL with severity of clinical Symptoms and level of functioning in bipolar and unipolar depressive patients group.

\section{METHODS}

The QOL on the four domains of the World Health Organization Questionnaire on Quality of Life - Hindi version (WHOQOL-BREF) were compared between 30 subjects with bipolar depression and 30 subjects with unipolar depression. The subjects had to be in a moderate to severe depressive state (As confirmed by a Beck Depression Inventory total score $>16$ ) with minimum duration of illness being two years prior to the inclusion in the study. The factors that contribute or influence QOL (socio-demographic factors, severity of depression and level of functioning) were also studied. Obtained Data were analysed by using unpaired t test, Pearson's correlation coefficient and z - score.

\section{RESULTS}

The group of bipolar depressive patients obtained statistically significantly lower scores on all the subscales when compared with the unipolar depressive patients. No statistically significant differences appeared when comparing the WHOQOL-BREF scores with the demographic variables.

\section{CONCLUSIONS}

The present findings suggest that depressive patients with bipolar disorder have a poorer QOL in comparison to unipolar depressive patients.

\section{KEYWORDS}

Quality of Life, Bipolar Disorder, Depression.

HOW TO CITE THIS ARTICLE: Khan AA, Agrawal S, Qureshi R, et al. Quality of life in bipolar and unipolar depressive patients: clinical and socio-demographical correlates. J. Evolution Med. Dent. Sci. 2016;5(37):2207-2212, DOI: 10.14260/jemds/2016/513

\section{INTRODUCTION}

Bipolar disorder is a psychiatric disease characterized by recurrent mood episodes and varied course. It starts in younger age with 20 years as average age of onset, affects at least $1 \%$ of the population and is associated with considerable morbidity and mortality.(1) Suicide is very common in BPAD, about $15 \%$ patients commit suicide.(2) Since the disorder is fairly prevalent and starts early in life, it ranks $5^{\text {th }}$ in the WHO's list of diseases causing disability amongst young adults (i.e., 15-44 years of age) in year 2000.(3)

Financial or Other, Competing Interest: None.

Submission 26-03-2016, Peer Review 20-04-2016,

Acceptance 26-04-2016, Published 07-05-2016.

Corresponding Author:

Dr. Aftab Ahmed Khan,

Assistant Professor,

Department of Psychiatry,

NSCB Medical College,

Jabalpur, Madhya Pradesh.

E-mail: draftab79@yahoo.com

DOI: $10.14260 /$ jemds $/ 2016 / 513$
Increased morbidity and mortality in bipolar disorder is due to fact that a significant proportion of bipolar patients' do not receive optimal treatment for their illness for a variety of reasons. Sixty-nine percent patients reported misdiagnosed. $(4,5)$ Bipolar patients suffer from mood symptoms for an average of 8-10 years before receiving a correct diagnosis.(6) Compliance is a major issue, at any given time only $50 \%$ of the patients are in treatment.(7) about one third of patients do not adhere to treatment regimen, thus limiting potential benefits of treatment. $(8,9)$

In recent years, the concept of quality of life (QOL) has become increasingly relevant in bipolar depression research, since effective treatment from a bio psychosocial perspective is now regarded as the reduction of symptoms without compromising the patients' QOL. (10) Das et al. recently found that patients who screened positive for bipolar depression had lower mental and physical quality of life scores than those who Screened negative.(11) In other study it is found that quality of life level is lower in bipolar depression in comparison with 
unipolar depression.(12) Level of depressive symptoms.(13,14) female gender.(15) and time undiagnosed (16), have been put forward as predictors of worse quality of life in bipolar depression samples.

In the past, the first goal of bipolar disorder treatment was the reduction of symptoms of mania or depression, rather than the recovery of social functioning.(17) while these data suggest that it is critical to measure functional recovery in addition to syndromal recovery in bipolar patients. The cyclical nature of bipolar disorder, with its many remission and symptomatic periods of exacerbation, can affect an individual's functioning and significantly impact their overall quality of life. The majority of bipolar patients suffer symptoms most of time.(18) which would considerably affect their quality of life. Although QOL has been widely studied in patients with unipolar depression, few studies have adequately characterized the impairment in QOL in patients with bipolar disorders. Quality of life is a multidimensional concept, encompassing different aspects such as physical, emotional, social and functional well-being.(19)

There has been little empirical research assessing the impact of bipolar depression on patients. A handful of studies, which are there, have shown that it makes the quality of life poor.(20) the literature is sparse in comparing the differences between bipolar depression and unipolar depression with respect to their impact on QOL. The primary purpose of this analysis was to compare QOL in patients with Bipolar disorder who had currently/recently experienced depressive episodes with unipolar depressive patients using the WHO quality of life (WHO-QOL)-BREF version.

\section{METHOD}

\section{Aims and Objectives}

The aims of this study were (i) to compare Quality of Life (QOL) of patients with bipolar depression to those with unipolar depression and (ii) to assess the association of different domains of QOL with severity of clinical Symptoms and level of functioning in bipolar and unipolar depressive patients group.

\section{Subjects}

Data were collected on the basis of a single cross-sectional interview of 30 subjects with bipolar depression and 30 patients with unipolar depression, who attend psychiatry OPD at SMS Hospital, Jaipur and fulfilled the inclusion/exclusion criteria. A written informed consent was taken from all subjects. The diagnoses were ascertained by face-to-face clinical interview of the patients and their informants by the psychiatrists using the ICD-10 criteria. All consenting adults who fulfilled the inclusion criteria were first administered a specially designed proforma by the investigator which included the Socio- demographic data and Clinical profile sheet. For measuring depression in both groups Beck Depression Inventory was used in which score of $>16$ essential in all patients. GAF (Global assessment of functioning) was also used to measure level of functioning.

\section{Inclusion \& Exclusion Criteria}

Patients between 18-60 years of age fulfilling the ICD-10 criteria for moderate or severe depressive disorders (Score of $>16$ on Beck Depression Inventory) with minimum duration of illness being two years. There should be at least one hypo manic, manic, or mixed affective episode in the past in bipolar depressive patients. Illiterate, uncooperative patients with any other co morbid major psychiatric disorder or any chronic physical illness, organic brain disorder or substance dependence were excluded from the study.

\section{Assessment Instruments WHO Quality of Life (WHO-QOL)-BREF Version}

Quality of life was assessed with the Hindi version of the WHO Quality of Life Measure- Abbreviated Version (WHOQOLBREF). The WHOQOL is a generic self-report instrument for the assessment of QOL. We used the 26-item version, WHOQOL-BREF (21) because it is brief, is useful in clinical evaluations, and is thought to be sensitive to health-related QOL status of people with long-term psychiatric illness. The WHOQOL-BREF provides measurement of the following four domains: physical, psychological, social relationship, and environment. The physical domain has questions related to daily activities, treatment compliance, pain and discomfort, sleep and rest, energy and fatigue. The psychological domain assesses positive and negative feelings, self-esteem body image and physical appearance, personal beliefs, and attention. The social relationship domain covers personal relationships, social support, and sexual activity. The environmental domain explores physical security, financial resources, health and social care and their availability, opportunities for acquiring new information for recreation and transport. All items are rated on a five-point Likert scale, higher scores reflecting better QOL. The internal consistency of the domain scores is generally good.(22)

\section{Beck Depression Inventory (BDI)}

The BDI was developed in the early 1960 to rate depression severity, with a focus on behavioural and cognitive dimension of depression. It had shown to have high reliability and validity. It contains 21 items each scoring 0 to 3 , of which 15 items deal with psychological symptoms and six are concerned with somatic ones.

\section{Global Assessment of Functioning Scale}

It measures the level of functioning of patient, it was developed in early 1990 to rate Axis IV of DSM IV. It is a clinician rated 100-Point Scale based on all available information with clear description of 10 points interval.

\section{Data Analysis}

The statistical treatment of the data was done by employing both nonparametric and parametric statistical measure. Nonparametric statistical measures included frequencies, percentages, whereas parametric statistical measures included unpaired t-test and z-test and Pearson's product moment correlation.

\section{RESULTS}

\section{Sociodemographic and Clinical Characteristics of Patient} and Control Groups

The sample was largely males (76.66\% in bipolar depression $\& 80 \%$ in unipolar depression group) with a mean age of 31.9 years in bipolar depression \& 36.3 in unipolar depression group. $63.33 \%$ of the bipolar depression sample was unemployed as compared to $20 \%$ in unipolar depression sample. The low employment rate in bipolar depression 
sample was due to that illness started early in life \& long duration of illness ( $>5$ years $=73.33 \%$ ) while in unipolar depression sample only $36.66 \%$ patients suffer from long duration of illness. Only $13.33 \%$ patients in bipolar depression sample earned more than 3000 rupees while in unipolar depression sample it is $50 \%$ patients. Study also shows that only $10 \%$ patients in bipolar depression sample having postsecondary/higher secondary qualification while in unipolar depression sample $46.67 \%$ patients were graduates/post graduates. The severities of depressive symptoms were high in bipolar depression group (35.67\%) in comparison to unipolar depression group (25.13\%).

\begin{tabular}{|c|c|c|}
\hline Variable & $\begin{array}{c}\text { Bipolar } \\
\text { Depression } \\
n=30\end{array}$ & $\begin{array}{c}\text { Unipolar } \\
\text { Depression } \\
\mathbf{n}=\mathbf{3 0}\end{array}$ \\
\hline $\begin{array}{l}\text { Age in (Years)- mean } \\
\text { (SD) }\end{array}$ & $31.90(7.16)$ & $\begin{array}{c}36.30 \\
(11.23)\end{array}$ \\
\hline $\begin{array}{l}\text { Sex } \\
\text { 1. Male } \\
\text { 2. Female }\end{array}$ & $\begin{array}{c}23(76.66) \\
7(23.34)\end{array}$ & $\begin{array}{l}24(80.0) \\
6(20.0)\end{array}$ \\
\hline Marital Status & & \\
\hline $\begin{array}{ll}\text { 1. } & \text { Single } \\
\text { 2. } & \text { Married } \\
\text { 3. } & \text { Remarried } \\
\text { 4. } & \text { Widowed } \\
\text { 5. } & \text { Divorced } \\
\text { 6. } & \text { Separated }\end{array}$ & $\begin{array}{c}14(28.0) \\
34(68.0) \\
- \\
2(4.0) \\
- \\
-\end{array}$ & $\begin{array}{c}10(21.3) \\
36(76.6) \\
- \\
- \\
- \\
1(2.1)\end{array}$ \\
\hline $\begin{array}{l}\text { Occupation } \\
\text { 1. Professional/Semiprof./ } \\
\text { Skilled Worker/ } \\
\text { 2.Farmer/Semi } \\
\text { skilled/labours } \\
\text { 3..Unemployed/ } \\
\text { Housewife/Student/ } \\
\text { Retired }\end{array}$ & $10(33.3)$ & $\begin{array}{c}14(46.67) \\
7(23.33) \\
9(30.0)\end{array}$ \\
\hline $\begin{array}{l}\text { Education } \\
\text { 1. Illiterate } \\
\text { 2. Middle } \\
\text { 3. secondary/higher } \\
\text { secondary } \\
\text { 4. Graduate/Post } \\
\text { Graduate }\end{array}$ & $\begin{array}{c}- \\
4(13.3) \\
23(76.67) \\
3(10.0)\end{array}$ & $\begin{array}{c}- \\
5(16.67) \\
11(26.67) \\
14(46.67)\end{array}$ \\
\hline $\begin{array}{l}\text { Monthly Income } \\
\text { 1. nil } \\
\text { 2. }<\text { <3000 } \\
\text { 3. }>3000\end{array}$ & $\begin{array}{l}19(63.33) \\
7(23.33) \\
4(13.33)\end{array}$ & $\begin{array}{c}6(20.0) \\
9(30.0) \\
15(50.0)\end{array}$ \\
\hline $\begin{array}{l}\text { Religion } \\
\text { 1. Hindu } \\
\text { 2. } \text { Muslim }\end{array}$ & $\begin{array}{c}27(90.0) \\
3(10.0)\end{array}$ & $30(100)-$ \\
\hline $\begin{array}{l}\text { Family Type } \\
\text { 1. Nuclear } \\
\text { 2. Joint/Others } \\
\end{array}$ & $\begin{array}{l}20(66.64) \\
10(33.34) \\
\end{array}$ & $\begin{array}{l}18(60.0) \\
12(40.0)\end{array}$ \\
\hline $\begin{array}{l}\text { Locality } \\
\text { 1. } \text { Urban } \\
\text { 2. } \text { Rural }\end{array}$ & $\begin{array}{l}19(63.34) \\
11(37.66)\end{array}$ & $\begin{array}{c}26(86.67) \\
4(13.33)\end{array}$ \\
\hline $\begin{array}{l}\text { Table1: Socio-Den } \\
\text { Depression and } U\end{array}$ & $\begin{array}{l}\text { raphic Data } \\
\text { lar Depress }\end{array}$ & $\begin{array}{l}\text { Bipolar } \\
\text { group }\end{array}$ \\
\hline
\end{tabular}

\begin{tabular}{|c|c|c|c|c|}
\hline Variable & $\begin{array}{c}\text { Bipolar } \\
\text { Depression } \\
(\mathbf{n}=\mathbf{3 0}) \\
\text { Mean (SD) }\end{array}$ & $\begin{array}{c}\text { Unipolar } \\
\text { Depression } \\
(n=30) \\
\text { Mean (SD) }\end{array}$ & $\begin{array}{c}\text { P- } \\
\text { Value }\end{array}$ & $\begin{array}{l}\text { Signi- } \\
\text { ficance }\end{array}$ \\
\hline $\begin{array}{c}\text { Total BDI } \\
\text { score } \\
\end{array}$ & $\begin{array}{l}35.67 \\
(5.83)\end{array}$ & $\begin{array}{l}25.13 \\
(6.80)\end{array}$ & $<.001$ & HS \\
\hline \multicolumn{5}{|l|}{$\begin{array}{l}\text { Duration } \\
\text { of Illness }\end{array}$} \\
\hline $1.2-5$ years & $8(26.67)$ & $19(63.34)$ & $>.05$ & NS \\
\hline 2.>5 years & $22(73.33)$ & $11(36.66)$ & $<.01$ & $S$ \\
\hline \multicolumn{5}{|l|}{$\begin{array}{c}\text { Family } \\
\text { History of } \\
\text { Psychiatric } \\
\text { Illness }\end{array}$} \\
\hline 1. Present & 11(36.67) & $2(6.67)$ & $<.01$ & $\mathrm{~S}$ \\
\hline 2. Absent & $19(63.33)$ & $28(93.33)$ & $>.05$ & NS \\
\hline $\begin{array}{c}\text { Table } 2 \\
\text { Depress } \\
\text { Bipolar }\end{array}$ & $\begin{array}{l}\text { stribution } \\
\text { Symptoms } \\
\text { pression al }\end{array}$ & $\begin{array}{l}\text { I Comparis } \\
\text { d Clinical C } \\
\text { Unipolar De }\end{array}$ & $\begin{array}{l}\text { f Seve } \\
\text { acter }\end{array}$ & $\begin{array}{l}\text { ty of } \\
\text { cs in } \\
\text { oup }\end{array}$ \\
\hline
\end{tabular}

Comparison of QOL between Patients and Control group Quality of life was measured by WHOQOL-Bref Version scale in both samples. Table-3 shows mean scores of scale on four subscales for bipolar depression and unipolar depression patients from this study. The mean scores were significantly low in bipolar depressed patients (P-value $<0.001)$ for following subscale: Physical Health, Psychological Health and Social Relationship. The scores were especially very low in psychological health subscale (9.27) in comparison to 22.63 in unipolar depression sample.

\begin{tabular}{|c|c|c|c|c|}
\hline $\begin{array}{c}\text { Variable } \\
\text { (WHOQOL } \\
\text { BREF) }\end{array}$ & $\begin{array}{c}\text { Bipolar } \\
\text { Depression } \\
(\mathbf{n}=\mathbf{3 0}) \\
\text { Mean (SD) }\end{array}$ & $\begin{array}{c}\text { Unipolar } \\
\text { Depression } \\
(\mathbf{n}=30) \\
\text { Mean (SD) }\end{array}$ & $\begin{array}{c}\text { P- } \\
\text { Value }\end{array}$ & $\begin{array}{c}\text { Signi- } \\
\text { ficance }\end{array}$ \\
\hline $\begin{array}{c}\text { Physical } \\
\text { Health }\end{array}$ & $13.13(2.32)$ & $21.90(6.07)$ & $<.001$ & $\mathrm{HS}$ \\
\hline $\begin{array}{c}\text { Psychological } \\
\text { Health }\end{array}$ & $9.27(3.13)$ & $22.63(7.16)$ & $<.001$ & $\mathrm{HS}$ \\
\hline $\begin{array}{c}\text { Social } \\
\text { Relationship }\end{array}$ & $4.67(1.35)$ & $13.57(5.00)$ & $<.001$ & $\mathrm{HS}$ \\
\hline Environment & $15.60(3.31)$ & $8.80(2.40)$ & $<.001$ & $\mathrm{HS}$ \\
\hline Total Score & $3.10(1.19)$ & $\mathbf{4 . 8 3 ( 1 . 8 6 )}$ & $<.001$ & $\mathrm{HS}$ \\
\hline \multicolumn{4}{|c|}{ Table 3: Comparison of Quality of life Scores between } \\
Bipolar Depression and Unipolar Depression group \\
\hline
\end{tabular}

\section{Comparison of Functioning between Patients and Control} group

In comparison of unipolar depression sample patients in bipolar depression sample shows significantly lower score in GAF-scale ( $\mathrm{p}$-value<.001) which shows increased functioning in unipolar depression patients. 


\begin{tabular}{|c|c|c|c|c|}
\hline $\begin{array}{c}\text { Variable } \\
\text { (GAF) }\end{array}$ & $\begin{array}{c}\text { Bipolar } \\
\text { Depression } \\
(\mathbf{n = 3 0 )} \\
\text { Mean (SD) }\end{array}$ & $\begin{array}{c}\text { Unipolar } \\
\text { Depression } \\
(\mathbf{n}=\mathbf{3 0}) \\
\text { Mean (SD) }\end{array}$ & $\begin{array}{c}\text { p- } \\
\text { Value }\end{array}$ & $\begin{array}{c}\text { Signi- } \\
\text { ficance }\end{array}$ \\
\hline $\begin{array}{c}\text { GAF } \\
\text { Score }\end{array}$ & $50.03(4.75)$ & $62.37(11.50)$ & $<.001$ & HS \\
\hline \multicolumn{4}{|c|}{$\begin{array}{c}\text { Table 4: Showing Comparison of Functioning } \\
\text { between Patients and Control group }\end{array}$} \\
\hline
\end{tabular}

Relationship of QOL with Socio-Demographic and Clinical Variables in Patients and Control Group
As shown in table $5 \& 6$ there were no statistically significant correlation between QOL score and socio demographic characteristics in bipolar \& unipolar depression. Table -5 shows that there was significant negative correlation between physical, psychological health and total score subscale and family history of psychiatric illness in bipolar depressive patients. BDI total score had significant negative correlation with all domains of QOL scale except physical health and social relationship in bipolar depressive patients. There were no statistically significant correlation between all QOL parameters and clinical characteristics in Patients with unipolar depression but there is significant negative correlation of all domains of QOL with total BDI score except social relationship domain (Table-7).

\begin{tabular}{|c|c|c|c|c|c|}
\hline Variable & Physical Health & Psychological Health & Social Relationship & Environment & Total Score \\
\hline Age in (years) & -.124 & .181 & -.315 & -.240 & .196 \\
\hline Sex & -.134 & -.248 & .136 & -.052 & -.178 \\
\hline Marital Status & -.018 & -.196 & -.060 & -.283 & -.171 \\
\hline Occupation & -.043 & .072 & .408 & .406 & -.051 \\
\hline Education & -.232 & .023 & .323 & .429 & .027 \\
\hline Monthly Income & .301 & .371 & .087 & .023 & .408 \\
\hline Family type & .203 & -.105 & -.140 & -.021 & -.059 \\
\hline Locality & -.076 & .245 & -.017 & .259 & .110 \\
\hline \multicolumn{7}{r}{} \\
\end{tabular}

${ }^{*} \mathrm{p}<.05,{ }^{* *} \mathrm{p}<.01$, Pearson product moment $(\mathrm{r})$

\begin{tabular}{|c|c|c|c|c|c|}
\hline Variable & Physical Health & Psychological Health & Social Relationship & Environment & Total Score \\
\hline Age in (years) & -.282 & .111 & .021 & .164 & .074 \\
\hline Sex & -.170 & -.040 & -.132 & -.056 & .268 \\
\hline Marital Status & .415 & .216 & .435 & .138 & .149 \\
\hline Occupation & -.135 & -.137 & -.266 & -.150 & .141 \\
\hline Education & .025 & .248 & -.105 & .210 & -.072 \\
\hline Monthly Income & .114 & .471 & .026 & .283 & .150 \\
\hline Family type & .191 & -.293 & -.006 & -.381 & -.239 \\
\hline Locality & -.349 & -.103 & -.417 & -.035 & -.123 \\
\hline \multicolumn{7}{r|}{ Table 6: Correlation between Quality of life Parameters (WHOQOL) and } \\
\\
Socio Demographic Characteristics in Patients with Unipolar Depression (n-30) \\
\hline
\end{tabular}

${ }^{*} \mathrm{p}<.05,{ }^{* *} \mathrm{p}<.01$, Pearson product moment $(\mathrm{r})$

\begin{tabular}{|c|c|c|c|c|c|}
\hline Variable & $\begin{array}{c}\text { Physical } \\
\text { Health }\end{array}$ & $\begin{array}{c}\text { Psychological } \\
\text { Health }\end{array}$ & $\begin{array}{c}\text { Social } \\
\text { Relationship }\end{array}$ & Environment & $\begin{array}{c}\text { Total } \\
\text { Score }\end{array}$ \\
\hline Duration of illness & -.063 & -.214 & .130 & -.196 & -.013 \\
\hline Family History of psychiatric illness & $-.374^{*}$ & $-.466^{* *}$ & .017 & .163 & $-.516^{* *}$ \\
\hline Total BDI score & -.315 & $-.554^{* *}$ & -.290 & $-.414^{*}$ & $-.551^{* *}$ \\
\hline
\end{tabular}

Table 7: Correlation between Quality of Life Parameters (WHOQOL) with Severity of

Depression \& clinical Characteristics in Patients with Bipolar Depression (n-30)

${ }^{*} \mathrm{p}<.05,{ }^{* *} \mathrm{p}<.01$, Pearson product moment(r)

\begin{tabular}{|c|c|c|c|c|c|}
\hline Variable & $\begin{array}{c}\text { Physical } \\
\text { Health }\end{array}$ & $\begin{array}{c}\text { Psychological } \\
\text { Health }\end{array}$ & $\begin{array}{c}\text { Social } \\
\text { Relationship }\end{array}$ & Environment & $\begin{array}{c}\text { Total } \\
\text { Score }\end{array}$ \\
\hline Duration of illness & .252 & .121 & .352 & .165 & .031 \\
\hline $\begin{array}{c}\text { Family History of psychiatric } \\
\text { illness }\end{array}$ & .128 & -.210 & -.022 & -.032 & -.096 \\
\hline Total BDI score & $-.392^{*}$ & $-.607^{* *}$ & -.360 & $-.369^{*}$ & $-.448^{*}$ \\
\hline \multicolumn{6}{r}{} \\
\hline
\end{tabular}

${ }^{*} \mathrm{p}<.05,{ }^{* *} \mathrm{p}<.01$, Pearson product moment(r) 


\section{Relationship of QOL with Functioning in Patients and} Control Group

GAF score had significant positive correlation with psychological domain of Quality of life \& Total QOL Score in bipolar depressive patients while in unipolar depressive patients GAF score had significant positive correlation with Physical Health, Psychological Health and Total QOL Score.

\begin{tabular}{|c|c|c|c|c|c|}
\hline Variable & $\begin{array}{c}\text { Physical } \\
\text { Health }\end{array}$ & $\begin{array}{l}\text { Psycho- } \\
\text { logical } \\
\text { Health }\end{array}$ & $\begin{array}{l}\text { Social } \\
\text { Relation- } \\
\text { ship }\end{array}$ & $\begin{array}{c}\text { Environ- } \\
\text { ment }\end{array}$ & $\begin{array}{l}\text { Total } \\
\text { Score }\end{array}$ \\
\hline $\begin{array}{c}\text { GAF } \\
\text { (Bipolar } \\
\text { depression } \\
\text { group) }\end{array}$ & .112 & $.392^{*}$ & .178 & .204 & $.376^{*}$ \\
\hline $\begin{array}{c}\text { GAF } \\
\text { (Unipolar } \\
\text { depression } \\
\text { group) }\end{array}$ & $.514^{* *}$ & $.591^{* *}$ & $.371^{*}$ & .224 & $.563^{* *}$ \\
\hline \multicolumn{6}{|c|}{$\begin{array}{c}\text { Table 9: Correlations of Global Assessment of } \\
\text { functioning with Quality of life in Patients with Bipolar } \\
\text { and Unipolar Depression }\end{array}$} \\
\hline
\end{tabular}

${ }^{*} \mathrm{p}<.05,{ }^{* *} \mathrm{p}<.01$, Pearson product moment( $\left.\mathrm{r}\right)$

** Correlation is significant at the 0.01 level (2-tailed).

\section{DISCUSSION}

In both groups male patients are more as compare to female patients with relatively younger age group in bipolar depression group. High unemployment and low education rate in bipolar depression group as compared to unipolar depression group is due to that in bipolar depression group illness started early in life with severe depressive symptoms \& long duration of illness ( $>5$ years $=73.33 \%$ ) while in unipolar depression sample only $36.66 \%$ patients suffer from long duration of illness as shown in earlier studies.(23,24) The mean level of functioning of bipolar depressive patient is 50.03 and 62.37 in unipolar depression sample which shows than unipolar depression patients were more functional.

The mean Quality of life scores as measured by WHOQOL-Bref were very low in bipolar depressed patients for Physical Health, Psychological Health and Social Relationship subscales. This might be due to poor social support and personal relationship in bipolar affective disorder in comparison to unipolar depression. Fernando Kratz et al.(20) also found that severity of depressive symptoms correlated negatively with poor QOL. The scores were especially very low in psychological health subscale (9.27) for bipolar depression in comparison to 22.63 in unipolar depression sample. Possible reason for poor score of psychological health domain in bipolar depressive patients and relatively better score in unipolar depressed group could be the cognitive bias of the patient.

Because of their illness, bipolar depressed patients see themselves in and the future in negative terms and tend to evaluate their personal relationships and social support negatively.(25) unipolar depressions on the other hand had comparatively low depression scores, and thus there were fewer or no cognitive biases of this kind thus leading on to relatively better score. Bipolar depression and unipolar depression groups showed statistically significant difference in the duration of illness ( $p$-value <.01). Duration of illness was more in bipolar depression. This may be because unipolar depression usually responds better to the treatment.(26) Bipolar depressive patients had significantly higher score on Beck Depression Inventory ( $p$-value<.001). In comparison of unipolar depression sample, patients in bipolar depression sample showed significantly lower score in GAF-scale ( $p$ value $<.001$ ) which shows increased functioning in unipolar depression patients.

Although both samples showed low QOL scores but bipolar depression sample reported significantly low score on all domains of QOL indicating that bipolar subjects experience considerable impairment(p-value<.001). The poorer QOL in bipolar depressed subjects could be because the patients in the present study group had less severe depression. The results are similar to those reported in earlier study by Yatham LN et al. ${ }^{12}$ No statistically significant correlation was found between Socio demographic factors and QOL in both study and control group. Only monthly income had significant positive correlation with Global assessment of functioning in study group.

This may be due to small sample size $(\mathrm{N}=30)$ in both study and control group. Past history of psychiatric illness correlated negatively with physical health and psychological health domains of QOL in bipolar depression patients. This may be due to long duration of illness, unemployment and more disability symptoms in bipolar depressive group. Severity of depression significantly negatively correlated with all domains of QOL in bipolar depression patients except physical health and social relationship, which shows that with increasing in severity of depression QOL of patient also become poor.

\section{SUMMARY AND CONCLUSION}

The results of our study demonstrated that bipolar depressive patients had significantly poor quality of life as compared to patients with unipolar depression who had better quality of life in all domains. Quality of Life of bipolar depressive patients not statistically significantly correlated with all sociodemographic variables but correlated significantly with some clinical and psychological variables.

\section{Implication of Study}

This study provides additional evidence that bipolar depression is associated with poorer quality of life compared to unipolar depression.

Interventions targeting rehabilitation and functional enhancement may be helpful to improve Quality of life, especially among subjects with bipolar depression.

\section{REFERENCES}

1. Weissman MM, Bland RC, Canino GJ, et al. Crossnational epidemiology of major depression and bipolar disorder. JAMA 1996;276(4):293-299.

2. Goodwin FK, Jamison KR. Manic-depressive illness. New York: Oxford University Press 1990;2 ${ }^{\text {nd }}$ edn.

3. Murray CJ, Lopez AD. Global mortality,disability and the contribution of risk factors: global burden of disease study. Lancet 1997;349(9063):1436-1442.

4. Akiskal HS, Maser JD, Zeller PJ, et al. Switching from unipolar to bipolar II. An 11-year prospective study of clinical and temperamental predictors in 559 patients. Arch Gen Psychiatry 1995;52(2):114-123. 
5. Ghaemi SN, Sachs GS, Chiou AM, et al. Is bipolar still underdiagnosed? Are antidepressant overutilized? J Affect Disord 1999;52(1-3):135-144.

6. Lish JD, Dime-Meenam S, Whybrow PC, et al. The national depressive and manic-depressive association (DMDA) survey of bipolar members. J Affect Disord 2004;31:281284.

7. Parikh SV, Wasylenki D, Goering P, et al. Mood disorders: rural/urban differences in prevalence, health care utilization and disability. Ontario J Affect Disord 1996;38(1):57-65.

8. Lingum R, Scott J. Treatment non-adherence in affective disorders. Acta psychiatr Scand 2002;105(3):164-172.

9. Scott J, Pope M. Nonadherence with mood stabilizers: prevalence and predictors. J Clin Psychiatry 2002;63(5):384-390.

10. Awad AG, Hogan TP, Voruganti LN, et al. Patients subjective experiences on antipsychotic medications: implications for outcome and quality of life. International Clinical Psychopharmacology 1995;10(3):123-132.

11. Das AK, Olfson M, Gameroff MJ, et al. Screening for bipolar disorder in a primary care practice. Journal of the American Medical Association 2005;293(8):956-963.

12. Yatham LN, Lecrubier Y, Fieve RR. Quality of life in patients with unipolar I depression: data from 920 patients. Bipolar Disorder 2004;6(5):379-385.

13. Russo J, Roy-Byrne P, Reeder D, et al. Longitudinal assessment of quality of life in acute psychiatric inpatients: reliability and validity. Journal of Nervous and Mental Disorder 1997;185(3):166-175.

14. Vojta C, Kinosian B, Glick H, et al. Self-reported quality of life across mood states in bipolar disorder. Comprehensive Psychiatry 2001;42(3):190-195.

15. Robb JC, Young LT, Cooke RG, et al. Gender differences in patients with bipolar disorder influence outcome in the medical outcomes survey (SF-20) subscale scores. Journal of Affective Disorders 1998;49(3):189-193.
16. Gazalle FK, Andreazza AC, Cereser KM, et al. Clinical impact of late diagnosis of bipolar disorder. Journal of Affective Disorders 2005;86(2-3):313-316.

17. Rosa AR, Reinares M, Franco $C$, et al. Clinical predictors of functional outcome of bipolar patients in remission. Bipolar Disord 2009;11(4):401-9.

18. Fava G. Subclinical symptoms in mood disorders. pathophysiological and therapeutic implications. Psychol Med 1999;29(1):47-61.

19. Guyatt G, Fenny D, Patric D. Measuring health-related quality of life. Ann Intern Med 1993;118(8):622-629.

20. Fernado Kratz Gazalle, Ana Cristina Andreazza, Pedro Curi Hallal. Bipolar depression the importance of being on remission. Rev Bras Psiquiatr 2006;28(2)93-96.

21. WHOQOL Group. Development of the World Health Organization WHOQOL-BREF quality of life assessment. Psychological Medicine 1998;28:551-558.

22. Saxena S, Chandramani K, Bhargava R. WHOQOL Hindi: a questionnaire for assessing quality of life in health care setting in India. Natl Med J India 1998;11(4):160-166.

23. Judd LL, Akiskal HS, Schettler PJ, et al. The long-term natural history of the weekly symptomatic status of bipolar I disorder. Arch Gen Psychiatry 2002;59(6):530537.

24. Judd LL, Akiskal HS, Schettler PJ, et al. A prospective investigation of the natural history of the long-term weekly symptomatic status of bipolar II disorder. Arch Gen Psychiatry 2003;60(3):261-269.

25. Hirschfeld RM, Lewis L, Vornik LA. Perception and impact of bipolar disorder: how far have we really come? result of the national depressive and manic depressive association 2000 survey of individual with bipolar disorder. J Clin Psychiatry 2003;64(2):161-174.

26. Szmukles GI, Burgers P, Herman H. Caring of relatives with serious mental illness: the development of experience of care giving inventory. Soc Psych Epidem 1996;31(3):134-4. 